\title{
ORGANIZATIONAL PREPAREDNESS FOR ACCREDITATION OF COMMUNITY HEALTH CENTER ON THE BORDERS
}

\author{
Dolvianus Yohanes Atok, Serlie K. A Littik, Hyronimus A. Fernandez
}

Masters Program in Public Health, Universitas Nusa Cendana

\begin{abstract}
Background: Accreditation program aims to improve the quality of health care. It assesses the structure, process, output, and the organization of healthcare. Several studies have showed that general accreditation program improves clinical outcomes. This study aimed to investigate the organizational preparedness for accreditation of community health center on the borders.

Subjects and Method: This was a cross-sectional study conducted at 12 community health centers in Malaka, East Nusa Tenggara. A total of 128 health professionals was selected for this study. The dependent variable was the preparedness of community health center accreditation. The independent variables were contextual factor, valence changes, information assessment, and organizational readiness. The data were collected by questionnaire and observation sheet. The data were analyzed by multiple logistic regression.

Results: Contextual factor (OR=0.01; $95 \% \mathrm{CI}=0.02$ to $0.14 ; \mathrm{p} \leq 0.001)$ was associated with the preparedness of community health center accreditation. The associations between information assessment $(\mathrm{OR}=5.71 ; 95 \% \mathrm{CI}=0.92$ to $35.37 ; \mathrm{p}=0.061)$, organizational readiness $(\mathrm{OR}=0.37 ; 95 \% \mathrm{CI}=0.06$ to $2.24 ; \mathrm{p}=0.282)$, and valence changes $(\mathrm{OR}=1.39 ; 95 \% \mathrm{CI}=0.37$ to $5.19 ; \mathrm{p}=0.619)$ and preparedness of community health center accreditation, were not statistically significant.
\end{abstract}

Conclusion: Preparedness of community health center accreditation is influenced by contextual factor.

Keywords: community health center, accreditation, contextual factor

\section{Correspondence:}

Dolvianus Yohanes Atok. Masters Program in Public Health, Universitas Nusa Cendana, Kupang, East Nusa Tenggara. Email: dolviatok5@gmail.com. Mobile: 082144940748.

The $5^{\text {th }}$ International Conference on Public Health Best Western Premier Hotel, Solo, Indonesia, February 13-14, $2019 \mid 460$ https://doi.org/10.26911/theicph.2019.04.36 